\title{
Job Satisfaction, and Psychological Distress Among Nigerian Security and Civil Defense Corps (NSCDC) Personnel Deployed for Operation Hadin Kai in Yobe State
}

\author{
Jurbe S. Bisji ${ }^{1} \quad$ Aboh J. Ogbole ${ }^{2} \quad$ Victor Adejo $^{3} \quad$ Susan A. Ogbole $^{4} \quad$ Sandra O. Ezeh $^{2}$ \\ Austine L. James ${ }^{5}$ Dangkat Bentu ${ }^{6}$ Taiwo Afolabi ${ }^{7}$ \\ 1.Department of Psychology, Nassarawa State University, Keffi, Nassarawa State \\ 2.Department of Behaviorial Medicine, 44 Nigerian Army Reference Hospital, Kaduna \\ 3.Synergos development innovations, Maitama, Abuja \\ 4.Department of Management, Vrije Universiteit, Brussels \\ 5.Department of Psychology, Plateau State University \\ 6.Department of Psychology, University of Jos \\ 7.Department of Sociology, University of Abuja
}

\begin{abstract}
The study assessed the relationship between job satisfaction and depression, anxiety and stress among Nigerian Security and Civil Defense Corps (NSCDC) personnel deployed for Operation Hadin Kai in Yobe state. A crosssectional survey design was adopted to obtain information from three hundred and twenty-five (325) personnel using purposive sampling method. Job Description Index (Smith, Kendall \& Hulin, 1969) and the Depression Anxiety and Stress Scale (Lovidond \& Lovibond, 1995) were adopted in the study. Majority of the respondents had moderate level of depression, $(\mathrm{n}=103,31.7 \%)$ and $31(9.5 \%)$ had extremely severe depression. Also, majority of the respondents had high level of anxiety, 111 (34.2\%). Furthermore, majority of the respondents had normal level of stress, $149(45.8 \%)$. In respect to job satisfaction, majority of the respondents had low level of satisfaction with their job, 297 (91.4\%). Also, there was a slight majority of the respondents who were satisfied with their pay $165(50.8 \%)$ as compared to those that were not, $160(49.2 \%)$. For promotion, majority were not satisfied, $308(94.8 \%)$. Low satisfaction with supervisor also had a majority of $308(94.8 \%)$ and also, majority were not satisfied with their co-workers, $316(97.2 \%)$. Gender $(X=6.660, \mathrm{p}<.05)$, Age $(X=6.781, \mathrm{p}<.05)$ and Rank $(X=3.799, \mathrm{p}<.05)$ were significant predictors of job satisfaction while psychological distress $(X=3.265$, $\mathrm{p}>.05)$, religion $(X=2.635, \mathrm{p}>.05)$ and marital status $(X=.640, \mathrm{p}>.05)$ were not found to be significant. Personnel of the NSCDC in Yobe were shown to have feelings of low satisfaction about their job with high psychological distress. Psychosocial interventions should be instituted by the military institution in collaboration with the NSCDC authorities to boost the morale of their personnel deployed to protect the integrity of the nation.
\end{abstract}

Keywords:Job Satisfaction, Psychological Distress, Depression, Anxiety, Stress,

DOI: $10.7176 /$ RHSS/11-16-03

Publication date:August $31^{\text {st }} 2021$

\section{INTRODUCTION}

The Nigerian Army has approved the renaming of the ongoing Counterinsurgency Operation in the North East region of Nigeria from Operation Lafiya Dole (OPLD) meaning Peace by Force to Operation Hadin Kai (OPHK) meaning "cooperation" in order to reposition for professionalism towards defeating all adversaries in a joint environment. This is due to the current security challenges which are intensified by socioeconomic and sociopolitical crises in the country which are putting security agents under pressure (Owolabi, 2021). This counter insurgency/counter terrorist operations in the Northeast have led to the deployment of military personnel, including paramilitary, to perform various roles towards restoring calm in the region. While the military remain in the fore front of the operations, the Nigerian Security and Civil Defence Corps (NSCDC) have equally been deployed to provide complimentary services to those of the military. These deployments have continued to increase job demands on these personnel particularly as it pertains to securing life and property with a backdrop on psychological wellbeing.

Psychological wellbeing of employees has continued to attract concerns and attention by employers, researchers and mental health professionals, (Saka, Kamai \& Alabi, 2018). This is because every organization needs employees who are in good psychological state in order to endure ongoing changes in the world of work. Karimu, (2015), highlighted that, in order to guarantee employee functionality, the welfare of employees under unfriendly conditions should be of paramount importance as in the case with personnel deployed in the Northeast. It is in relation to this that Obiora and Inuoha, (2013), identified increasing evidence that attitudes about one's job such as stress and job satisfaction are critical towards efficient and effective functioning. Gradual and progressive job stress resulting to psychological distress can impair well-being over time.

Unfriendly job environments characterized by job stress have equally shown to impact of job satisfaction 
(Riaz, Ahmad, Riaz, Murtaza, Khan \& Firdous, 2016; Ehsan \& Ali, 2019; Sardin, Ismail, Samah, Bukar \& Aminudin, 2015). One of the major psychological consequences of job stress is a decrease in job satisfaction which can lead to reduction in ones commitment to work, (Singh, Amiri \& Sabbarwal, 2019; Lee, Lee, Liao \& Chang, 2009). Atif, Boghsani, Javed, Javed, and Javed (2018) have confirmed that perpetual relation between job dissatisfaction and psychological distress exists which may be due to mental health burden on personnel. Garbarino, Cuomo, Chiorri, Magnavita, (2013) suggested that work-related stress may also play a role in mental health. The consequences of stress on the mental health can thus be especially serious not only for the heightened risk to their individual health, but also leading to an increased risk of impaired occupational functioning that could jeopardies the safety and health of their colleagues and the general population.

Many studies have demonstrated a usually large impact of job satisfaction on motivation of workers as well as their performance (Aziri, 2011). Godwin, (1993) perceives job satisfaction as a general positive orientation of an individual towards his job. Ang, Bartram, McNeil, Leggat and Stanton (2013) added that an employee's overall sense of wellbeing at work combining psychological, physiological and environmental circumstances explains job satisfaction. Job satisfaction has been seen to positively correlate with organization performance, (Latif, Ahmad, Qasim, Mushtaq, Ferdoos \& Naeem, 2019; Chiedu, Long \& Ashar, 2017). Similarly, Ikyanyon and Ucho, (2013) found that employees who experience high levels of job satisfaction perform higher than those who experience low levels of job satisfaction.

Researches have continue to identify several factors that relate to job satisfaction, majority of which can be grouped into personal and environmental factors, where researchers still argue that the work environment is a better predictor of job satisfaction, (Zhoa, Thurman, \& He 1999; Boke \& Nalla, 2009; and Saka, Kamai \& Alabi, 2018). Of these environmental factors, pay and salary, promotions, working conditions, leadership and supervision, social relationships and the job itself have been found to influence the level of job satisfaction an individual derives from his work, (Okwaraji \& Agwu, 2015; Selic, Petek \& Pesjak, 2012; Bello, Ajayi \& Asuzu, 2018; Muideen, 2018 and Chinedu, Long \& Ashar, 2017).

In studies conducted by Aderemi, Titus and Olansile, (2019), among police officers in Osun state command and Adelakun, Kabir, Ibrahim, Adedeji, and Akinade, (2019) in assessing perceived effect of improving labour conditions and paramilitary training on staff efficiency in Kainji Lake National Park, salary/compensation were considered to be important working condition for job efficiency, thus contributing significantly to job satisfaction. Drawing from the above, it is established that how satisfied employees are can affect how well they function on their job. Considering the strategic role of the paramilitary in support of military operations in the Northeast and the country at large through various internal security operations with the core mandate of protecting lives and property, it is important that the psychological wellbeing of personnel in pertaining to occupational conditions towards maintaining job satisfaction in the face of varying job and deployment conditions remains robust for operational effectiveness and professionalism.

Studies have also related psychological distress such as depression with some socio-demographic variables like gender, marital status, household composition, living arrangements, ethnicity, education and occupational class to examine whether there is significant relationship or not. Gender may be an important demographic characteristic to be considered in the experience of depression and Okhakhume, Aroniyiaso and Odetunde (2018) showed that there was no gender difference in how male and female experience depression. Therefore, this study seeks to assess the relationship between job satisfaction and psychological distress among NSCDC personnel deployed in support of military operation (Ops Hadin Kai-Cooperation) in Yobe state, Northeast Nigeria.

\section{STATEMENT OF THE PROBLEM}

The crises situation of Nigeria due to activities of Boko Haram, Herdsmen, Bandits and kidnappers has threatened the existence of the country as a nation. Between the start of January and the end of November, 2020 alone, there were a total of 142 incidences involving Boko Haram and ISWAP insurgents in three North East States of Borno, Adamawa and Yobe making an average of 13 incidences every month. Over 1600 people were reported killed in 125 incidences in 2020 alone (Reliefweb, 2020) with over 2.9 million internally displaced persons (IDPs) in North eastern Nigeria as reported by the United Nations Refugee Agency, United Nations High Commissioner for Refugee in 2021 with a daily reports on newspapers and other media agencies on attacks and on many occasions, death of military personnel who are tasked with the role of maintaining law and order.

The role of the Nigerian Security and Civil Defence Corps (NSCDC) towards the fight against insurgency in the country is worthy of commendation. It has been reported that the NSCDC about six years ago have trained 10,000 corps to fight insurgency (Awosiyan, 2015) in the area of capacity building and counter terrorism in Isreal, Pakistan, Italy, and also in Nigeria with the Nigerian Army School of Counter Terrorism and Counter Insurgency with the aim of tackling insurgency in the country. It is in view of the internal security challenges that the Nigerian Government deployed the NSCDC with the mandate of assisting the military in the management of the threats to internal security in the country.

Despites the supports of the NSCDC in the fight against insurgency, it has been observed that more has to 
be done by the government to improve their performance especially through the recruitment process and training to enhance their skills (Idowu, 2019) and in areas of welfare which helps in improving personnel's job satisfaction. To the best of the researcher's knowledge, no research has been conducted involving the personnel of the NSCDC to study their level of psychological distress and its relationship to job satisfaction. While attention is more focused on the Nigerian Military such as the Army, Air Force and Navy including Police, the NSCDC has received less attention by the research community. This study, therefore, is aim to fill the void by considering how psychological distress relates to job satisfaction among NSCDC personnel in Yobe State, North East Nigeria.

\section{OBJECTIVE OF THE STUDY}

The general objective of the study is to assess the relationship between job satisfaction and psychological distress among Nigerian Security and Civil Defense Corps (NSCDC) personnel in Yobe state. Other specific objectives include:

i. To investigate the levels of job satisfaction and psychological distress among NSCDC personnel supporting the Ops Hadin Kai in North East Nigeria.

ii. To investigate the relationship of job satisfaction and psychological distress of NSCDC personnel supporting the Ops Hadin Kai in North East Nigeria.

iii. To investigate the role of demographic variables on psychological distress.

\section{HYPOTHESIS}

i. There will be a significant relationship between job satisfaction and psychological distress of NSCDC personnel supporting the Ops Hadin Kai in North East Nigeria.

ii. Demographic variables of age, gender, rank, religion and marital status will significantly predict psychological distress of NSCDC personnel supporting the Ops Hadin Kai in North East Nigeria.

\section{METHOD}

\subsection{Participants and Setting}

A questionnaire-based cross-sectional survey design was adopted to obtain information from three hundred and twenty-five (325) Nigerian Security and Civil Defence Corps in Yobe state, Nigeria. Participants were recruited majorly using purposive sampling method. Demographic characteristics of participants majority of the respondents fall within the age bracket of 21-30 years, $164(50.5 \%)$ and the least being $1(.3 \%)$ within the age bracket of 51 years and above comprised majorly of male personnel $262(80.6 \%)$ and only $63(19.4 \%)$ females. Other characteristics revealed junior ranked officers constituted most of the participants, $279(85.8 \%)$ with only $46(14.2 \%)$ senior ranked officers. A higher proportion of participants were Christians, $198(60.9 \%)$ followed by Islam, 127 (39.1\%). 240 (73.8\%) were married while $85(26.2 \%)$ were singles. Majority of the personnel had work experience of between 6 to 10 years followed by those with 16-20 years and the least with 21 years and above.

\section{INSTRUMENTS}

\subsection{Job Description Index}

The Job Description Index (JDI) is a 72-item inventory designed to assess views clients have about 5 aspects of their jobs; work on present job, present pay, opportunities for promotion, supervision on present job and people of present job hence, to determine the feeling of satisfaction with each of the job components. The instrument was originally developed by Smith, Kendall and Hulin, (1969) and adopted for use of professionals in Nigeria after proper standardization to enhance its suitability and relevance for Nigerians by Omoluabi, (1997). The instrument can be administered in a group and to individuals after adequate establishment of rapport. The average internal consistency values for 'the revised JDI were $0.87,0.88,0.86,0.88$ and 0.89 for satisfaction with pay promotion, co-workers, work and supervision respectively' (Kinicki, Mckee-Ryan, Schriesheim, \& Carson, 2002). Ijide (2012) in a study "Development and Validation of Nigerian Army Commanding Officers Job Descriptive Index" found the correlation coefficient of the scale ranging between 0.6 and 0.78 .

\subsection{Depression Anxiety and Stress Scale}

The Depression Anxiety and Stress Scale (Lovidond \& Lovibond, 1995) is adapted to measure psychological distress in the study. It is a self-report instrument shown to be a valid and reliable measure of the dimensions of depression, anxiety, and stress separately but also taps into a more general dimension of psychological distress. The 21 items DASS are each rated on a 4-point scale of how much each particular statement applies to the individual. Taoreed, Jinadu and Adeboye (2013) in a study, aimed at validating a 42-item Depression, Anxiety and Stress Scale (DASS-42) with the Nigerian Military Population found that the 42 DASS had good Cronbach's alpha value of $0.89,0.91$ and 0.90 for depression, anxiety and stress subscales. The 21 item DASS was also 
validated for the current sample and internal consistency for the items shows a Cronbach's alpha of .71, .77 and .75 were obtained for depression, anxiety and stress subscales respectively.

\section{PROCEDURE}

Required permission in written was sorted from the Yobe State NSCDC command through the Headquarters Theatre Command Operation Hadin Kai NSCDC Liaison Officer. Upon obtaining approval, the researcher engaged some research assistants, given adequately briefed on the study. Necessary orientation was given to them on how to administer the instruments and procedures for data collection. Participants were briefed on the purpose of the study and were encouraged to complete the questionnaire correctly as it pertains to them. In following with adequate ethical consideration, 380 standardized questionnaires were distributed to participants using purposive sampling who met inclusion criteria for participation. However, 55 were discarded due to improper completion. Therefore, 325 questionnaires were used for analysis.

\section{DATA ANALYSIS}

In analysis of the data for the study, statistical techniques such as percentage, frequency, Chi Square were used. The results were tested at $\mathrm{p}<0.05$ level of significance.

\section{RESULTS}

Table 1: Level of Psychological Distress

Level of Psychological Distress

Depression

Normal
Mild
Moderate
Severe
Extremely Sever
Total

Anxiety

Stress

$\begin{array}{lc}\text { Normal } & 66 \\ \text { Mild } & 33 \\ \text { Moderate } & 51 \\ \text { Severe } & 64 \\ \text { Extremely Severe } & 11 \\ \text { Total } & 325\end{array}$

$\begin{array}{lcc}\text { Normal } & 149 & 45.8 \\ \text { Mild } & 65 & 20.0 \\ \text { Moderate } & 72 & 22.2 \\ \text { Severe } & 36 & 11.1 \\ \text { Extremely Severe } & 3 & .9 \\ \text { Total } & 325 & 100.0\end{array}$

Table 1 shows that majority of the respondents had moderate level of depression, 103 (31.7\%) with 31 $(9.5 \%)$ with extremely severe depression. Also, majority of the respondents had high level of anxiety, 111 $(34.2 \%)$ with only $66(20.3 \%)$ having normal level of anxiety. Finally, Majority of the respondents have normal level of stress, $149(45.8 \%)$ with only $3(.9 \%)$ having extremely severe stress. 
Table 2: Level of Job Satisfaction

\begin{tabular}{lccc}
\hline Level of Job Satisfaction & Frequency & Percent \% \\
\hline Work & Low & 297 & 91.4 \\
& High & 28 & 8.6 \\
Total & 325 & 100.0 \\
Pay & Low & 160 & 49.2 \\
& High & 165 & 50.8 \\
& Total & 325 & 100.0 \\
Promotion & Low & & 72.0 \\
& High & 234 & 28.0 \\
& Total & 91 & 100.0 \\
Supervisor & Low & 325 & 94.8 \\
& High & & 5.2 \\
& Total & 308 & 100.0 \\
& Low & 17 & 97.2 \\
& High & 325 & 2.8 \\
& Total & 316 & 100.0 \\
\hline
\end{tabular}

Table 2 shows that majority of the respondents had low level of satisfaction with their work, 297 (91.4\%). Also, there is a slight majority of the respondents who are satisfied with their pay $165(50.8 \%)$ as compared to those that are not, $160(49.2 \%)$. For promotion, majority were not satisfied, $308(94.8 \%)$, low satisfaction with supervisor also have a majority of $308(94.8 \%)$ and also, majority were not satisfied with their co-workers, 316 $(97.2 \%)$.

Table 3: Chi Square for Psychological Distress and Job Satisfaction

\begin{tabular}{|c|c|c|c|c|c|c|c|}
\hline & & \multicolumn{2}{|c|}{ Job Satisfaction } & \multirow[b]{2}{*}{ Total } & \multirow[b]{2}{*}{ DF } & \multirow[b]{2}{*}{$X$} & \multirow[b]{2}{*}{$\mathbf{P}$} \\
\hline & & Not Satisfying & Satisfying & & & & \\
\hline \multirow[t]{2}{*}{ Psych. Distress } & High & $207(72.1 \%)$ & $80(27.9 \%)$ & $287(100.0 \%)$ & 1 & $3.265^{\mathrm{a}}$ & .05 \\
\hline & Low & $22(57.9 \%)$ & $16(42.1 \%)$ & $38(100.0 \%)$ & & & \\
\hline \multirow[t]{2}{*}{ Gender } & Male & $193(73.7 \%)$ & $69(26.3 \%)$ & $262(100.0 \%)$ & 1 & $6.660^{\mathrm{a}}$ & .01 \\
\hline & Female & $36(57.1 \%)$ & $27(42.9 \%)$ & $63(100.0 \%)$ & & & \\
\hline \multirow[t]{2}{*}{ Age } & $<=30$ Years & $145(65.9 \%)$ & $75(34.1 \%)$ & $220(100.0 \%)$ & 1 & $6.781^{\mathrm{a}}$ & .01 \\
\hline & $>=31$ Years & $84(80.0 \%)$ & $21(20.0 \%)$ & $105(100.0 \%)$ & & & \\
\hline \multirow[t]{2}{*}{ Rank } & Non Commissioned & $191(68.5 \%)$ & $88(31.5 \%)$ & $279(100.0 \%)$ & 1 & $3.799^{\mathrm{a}}$ & .03 \\
\hline & Commissioned & $38(82.6 \%)$ & $8(17.4 \%)$ & $46(100.0 \%)$ & & & \\
\hline \multirow[t]{2}{*}{ Religion } & Islam & $96(75.6 \%)$ & $31(24.4 \%)$ & $127(100.0 \%)$ & 1 & $2.635^{\mathrm{a}}$ & .07 \\
\hline & Christianity & $133(67.2 \%)$ & $65(32.8 \%)$ & $198(100.0 \%)$ & & & \\
\hline \multirow[t]{2}{*}{ Marital Status } & Married & $172(71.7 \%)$ & $68(28.3 \%)$ & $240(100.0 \%)$ & 1 & $.640^{\mathrm{a}}$ & .25 \\
\hline & Singles & $57(67.1 \%)$ & $28(32.9 \%)$ & $85(100.0 \%)$ & & & \\
\hline
\end{tabular}

From table 3, job satisfaction, $(X=3.265, \mathrm{p}>.05)$, Gender $(X=6.660, \mathrm{p}<.05)$, Age $(X=6.781, \mathrm{p}<.05)$ and Rank $(X=3.799, \mathrm{p}<.05)$ were significant predictors of job satisfaction while religion $(X=2.635, \mathrm{p}>.05)$ and marital status $(X=.640, \mathrm{p}>.05)$ were not found to be significant.

\section{DISCUSSION}

This study revealed the presence of psychological distress (depression, anxiety and stress) and low levels of job satisfaction among the NSCDC personnel studied. Majority of the respondents had moderate level of depression, $103(31.7 \%)$ with $31(9.5 \%)$ manifesting extremely severe depression. Also, majority of the respondents had high level of anxiety, $111(34.2 \%)$ with only $66(20.3 \%)$ having normal anxiety while majority of the respondents had normal level of stress, $149(45.8 \%)$ with only $3(.9 \%)$ having extremely severe stress. The high level of psychological distress and low job satisfaction noticed in this study may be associated with the level of training and exposure of paramilitary profession coupled with the hazards of deployment to such dangerous locations, poor remuneration and the feeling by many of the participants that their work was not given adequate attention by appropriate authorities. Also, due to high level of unemployment in the country, some individuals may just accept any job which the NSCDC job may not be an exception, and the long run, prone to experience high psychological distress and low job satisfaction.

There appears to be a majority of the respondents who have low level of satisfaction with their work, 297 
(91.4\%). This finding is in line with the result of Yvonne, Rahman and Long (2014) that reported a moderate level of job satisfaction among their respondents and they explained that the display of the low job satisfaction may not be unconnected with the desire and enthusiasm of the personnel towards their work.

The first hypothesis which stated that there would be a significant relationship of job satisfaction and psychological distress of NSCDC personnel supporting the Ops Hadin Kai in North East Nigeria, which is supported in the study. This is indicate that the higher the level of psychological distress, the lower the level of job satisfaction. The finding is supported by the work of Adenuga (2015) who opined that psychological distress such as depression has a significant negative influence on job satisfaction of employee. It was further explained that a distressed worker cannot contribute optimally and may not be satisfied with their job (Adenuga, 2015). Thus, the personnel's low job satisfaction may be influenced by the nature of their work which might have been interpreted or perceived to be poor. This finding is also similar to the report of Moradi et al., (2014) who also found that psychological distress is associated with job satisfaction. Salma, and Hasan (2020) showed that employees with high level of job satisfaction will have low anxiety compared to employees with low level of job satisfaction. Anxiety may be evoked by some or a combination of situational and psychological variables. And to this end they are associated with one or the other facets of our life. For a man of modern world his job life is, probably, the most significant aspect. People engage themselves in some job where they spent more hours than in any others single activity, except in sleeping, in their lives. The personnel working in war zone might indicate some apprehension about and vague fears from some or many components of their jobs. As a result of interaction between their painful associations or experiences with job components, which are reflected in their overall behavior and adjustment at work. In essence, the NSCDC personnel who is experiencing a general feeling of vague fear and insecurity, and apprehensive mental state pertaining to the hazardous nature of his job is more likely to develop some low level of job satisfaction compared to another personnel who is anxious free.

Also, there was a relationship between stress and job satisfaction which was minimal. This finding is not in line with the report of Ismail, Ghani, Subhan, Joarder, and Ridzuan (2015) who deduced that physiological and psychological stresses have been recognized as important determinants of job satisfaction. Though the study showed the personnel were stressed to some extent, but that may not influence or relates to the job satisfaction. The plausible reason for this corroboration and confirmation might not be unconnected with the nature of the job which involves rendering of services by the NSCDC.

Hypothesis two predicted that there will be significant influence of some socio-demographic variable (gender, age, and rank) on psychological distress. Contrary to the findings of some studies (Okhakhume, et al., 2018), the study showed that gender, age and rank were significant predictors of psychological distress among the NCSCD personnel.

\section{RECOMMENDATIONS}

Steps like enhancing employees' job satisfaction should be taken to limit and curb occupational stress in the NCDSC in the North East where it appears that stressed personnel are not feeling satisfied about their job, in order to promote their interest to work and service to humanity.

Government should employ more psychologists in order to be giving adequate, suitable and optimal attention to job satisfaction, pay satisfaction and training of NSCDC personnel. Employers should find a way of rehabilitating personnel who exhibit high level of stress since it affects their services.

In addition, this study should also be expanded to other establishment and also be carried out in all major regions of Nigeria to have a broader view of job satisfaction in Nigeria in order to be compared with findings from other countries. This might give more insight into the influence of psychological distress and job satisfaction. Finally, some other factors especially the socio-demographic factors such as gender, age, economic status, religion, and education level should be considered in further studies. The reflection of the numerated limitations of this study primarily implores other researcher who wants to replicate this study to endeavor to use a large size of sample from all paramilitary organizations in several regions of Nigeria.

\section{CONCLUSION}

The rate of occurrence of psychological distress such as depression, anxiety and stress which this study showed is significantly connected to job satisfaction among personnel of the NSCDC calls for urgent attention by authorities concerned. Personnel with higher level of psychological distress tend to have lower job satisfaction compared to their counterparts with lower psychological distress. It therefore calls for mental health professionals to be incorporated in mental health service delivery to personnel assessed to have psychological distress and to also proffer the best solutions towards increasing the job satisfaction of personnel, while considering their exposure to the hazards that comes from working in such locations. Regular assessment of assessment of psychological distress and job satisfaction will enhance the performance of the personnel. Psychosocial interventions should be instituted by the military institution in collaboration with the NSCDC authorities to boost the morals of their personnel deployed to protect the integrity of the nation. 
Conflicts of Interest

The authors declare that they have no conflicts of interest.

\section{Data Availability}

The data used to support the findings of this study are available from the corresponding author upon request.

\section{Acknowledgments}

The authors acknowledge the immense support received by the Nigerian Security and Civil Defence Corps (NSCDC) in Yobe state, department of behavioral medicine, 44 Nigerian Army Reference Hospital, Kaduna, department of Psychology, Nassarawa State University, Plateau State University, department of management, Vrije Universiteit, Brussels, Synergos Development Innovations, Maitama, Abuja, and department of Sociology, University of Abuja. The authors appreciate these respective institutions and the study participants for their cooperation in the course of the research work.

\section{References}

Adelakun, K.M., Kabir, M.A., Ibrahim, A.O., Adedeji, A.S., \& Akinade, T.G. (2019). Perceived effect of improving labour condition and paramilitary training on staff efficiency in Kainji Lake National Park, Nigeria. Journal of Research in Forestry, Wildlife and Environment, 11(4), 11 - 19.

Adenuga, O.A. (2015). Impact of Occupational Stress on Job Satisfaction and Mental Health of First Bank Employees: Implication for Personnel Psychologists. American Journal of Psychology and Cognitive Science, 1 (1): $15-21$.

Aderemi, O., Titus, A.A., \& Olansile, S.B. (2019). Job satisfaction among police officers in Osun state commands: influence of perceived occupational stress and shift work. International Journal of Applied Psychology. 9(3): 91-97. doi:10.5923/j.ijap.20190903.03

Agbiboa, D.E. (2013). The ongoing campaign of terror in Nigeria: Boko Haram Versus the State. International Journal of Security and Development. 2(3), 1-18.

Ang, S.H., Bartram, T., McNeil, N., Leggat, S.G., \& Stanton, P. (2013). The effects of high- performance work systems on hospital employees work attitudes and intention to leave: a multi-level and occupational group analysis. The International Journal of Human Resource Management, 24:(16) 3086-3114. DOI: 10.1080/09585192.2013.775029.

Atif, K., Boghsani, G.T., Javed, A., Javed, A., \& Javed, S. (2018). Does lack of job satisfaction intensify psychological distress among clinicians, and vice versa? Electronic Journal of General Medicine, 15(5), 1-7.

Aziri, B. (2011). Job satisfaction. A literature review. Manag. Res. Pract., 3, 77-86.

Bello, S., Ajayi, D.T., \& Asuzu, M.C. (2018). Determinants of job satisfaction among physicians in public hospitals in Calabar. Nigeria Journal of Community Medicine and Primary Health Care. 30 (1) 19-33.

Boke, B., \& Nalla, M. (2009), Police organizational culture and job satisfaction: a comparison of law enforcement officers' perceptions in two midwestern states in the U.S. Journal of Criminal Justice and Security, 55-73.

Chiedu, C.K., Long, C.S., \& Ashar, H. (2017). The relationship among job satisfaction, organizational commitiment and employees' turnover at Unilever Corporation in Nigeria European Journal of Multidisciplinary Studies, 5(1), 370 - 383

Ehsan, M., \& Ali, K. (2019). The impact of work stress on employee productivity: based in the banking sector of Faisalabad, Pakistan. International Journal of Innovation and Economics Development, 4(6). 32-50.

Godwin, T.O. (1993) Factors affecting librarians job satisfaction: a report of two studies. Librarian Quarterly, 44, 97-110.

Idowu J. (2019). The Nigerian Security and Civil Defence Corps and Internal Security Management in Nigeria. Internal Security Management in Nigeria. Retrieved from www.researchgate.net/publication/334642536The-Nigerian-Security-and-Civil-Defence-Corps-and-Internal-Security-Management-in-Nigeria/

Ijide W. (2012). Development and Validation of Nigerian Army Commanding Officers Job Descriptive Index. he African Journal for the Psychological Study of Social Issues. 15 (1). Retrieved from https://www.ajol.info/index.php/ajpssi/article/view/79084

Ikyanyon, D.N., \& Ucho, A., (2013). Workplace bullying, job satisfaction and job performance among employees in a federal hospital in Nigeria. European Journal of Business and Management 5(23).

Ismail, A., Ghani, A.B.A., Subhan, M., Joarder, M.H.R. \& Ridzuan, A.A. (2015). The Relationship between Stress and Job Satisfaction: An Evidence from Malaysian Peacekeeping Mission. Mediterranean Journal of Social Sciences, 6 (4): $647-655$

Ismail, A., Saudin, N., Ismail, N., Samah, A.J.A., Bakar, R.A., \& Aminudin, N.N. (2015) Effect of workplace stress on job performance. Economic Review: Journal of Economics and Business, 13(1), 45-57.

Karimu, O.O. (2015). Effects of the Nigeria police force personnel welfare condition on performance. European 
Journal of Research and Reflection in Arts and Humanities, 3(1), 1-12.

Kinicki, A.J., Mckee-Ryan, F.M., Schriesheim, C.A., \& Carson, K.P. (2002). Assessing the construct validity of the job descriptive index: A review and meta-analysis. The Journal of Applied Psychology, 87(1), 14-32.

Kyko O.C. (2005). Instrumentation: know yourself and others. Longman, New york.

Latif, M.S., Ahmad, M., Qasim, M., Mushtaq, M., Ferdoos, A., \& Naeem, H. (2013). Impact of employee's job satisfaction on organizational performance. European Journal of Business and Management, 5(5), 166 171.

Lee, M.S., Lee, M., Liao, S., \& Chiang, F. (2009). Relationship between mental health and job satisfaction among employees in a medical center department of laboratory medicine. Journal of Formosan Medical Association, 108(2), $146-154$.

Lovibond, S.H. \& Lovibond, P.F. (1995). Manual for the depression anxiety \& stress scales, $2^{\text {nd }}$ ed. Sydney, psychology foundation.

Moradi, S., Farahnaki, Z., Akbarzadeh, A., Gharagozlou, F., Pournajaf, A., Abbasi, A.M., Hami, M., \& Karchani, M. (2014). The Relationship between Shift Work and Job Satisfaction among Nurses: a Crosssectional Study. International Journal of Hospital Research, 3(2): $63-68$.

Muideen F.O. (2018). Executive unconscious-bias and employee job satisfaction in government parastatals in Lagos state Nigeria. Business and Economic Journal, 1 - 4. Doi:10.4172/2151-6219.1000342

Nwagboso, I.R., Onuoha, B.C., \& Akhigbe, J.O. (2016). Leadership behaviour and employee job satisfaction among paramilitary workers in Benin City, Edo State. InternationaJournal of Advanced Academic Research, 2(11), $17-33$.

Obiora, C.A., \& Iwuoha, V.C (2013). Work related stress, job satisfaction and due process in Nigerian public service. European Scientific Journal, 9(20), 214 - 232.

Okhakhume A.S., Aroniyiaso O.T. \& Odetunde A.O. (2018). Demographic Variable and Job Stress as Predictors of Depression among Primary School Teachers in Lagos State of Nigeria. British Journal of Psychology Research, 6, (3), 32-44.

Okwaraji, F.E., \& Aguwa, E.N., (2015). Burnout, psychological distress and job satisfaction among secondary school teachers in Enugu, South East Nigeria. Journal of Psychiatry, 18(1). http://dx.doi.org/10.4172/19948220.1000198

Owolabi F. (2021). Lafiya Dole to Hadin Kai-Army renames operation to defeat Boko Haram. www.thecable.ng/lafia-dole-to-hadin-kai-army-renames-operation-to-defeat-boko-haram/amp

Reliefweb (2020). Chart of the week: Boko Haram fatalities in 2020. Retrieved from http://reliefweb.intt/map/nigeria/chart-week-boko-haram-fatalities-2020.

Riaz, M., Ahmad, N., Riaz, M., Murtaza, G., Khan, T., \& Firdous, H. (2016). Impact of job stress on employee job satisfaction. International Review of Management and Business Research, 5(4) 1370 - 1382.

Saka, S.A., Kamal, O., \& Alabi, O.T. (2018). Influence of perceived occupational stress on psychological wellbeing of federal road safety personnel in Nigeria. Journal of Clinical and Medical Sciences, 2:1, 1- 6 .

Salma U., Hasan M.M. (2020). Relationship between Job Satisfaction and Depression, Anxiety and Stress among the Female Nurses of Dhaka Medical College and Hospital, Bangladesh, Public Health Research, 10 (3), 94-102. doi: 10.5923/j.phr.20201003.02.

Selič, P., Petek, D., \& Pesjak, K. (2012). Healthy, but are they satisfied? Factors associated with job satisfaction in professional soldiers of the Slovenian Armed Forces. J def manag, 2(2), 1 - 8. doi: 10.4172/21670374.1000103

Singh, M.M., Amiri, M., \& Sabbarwal, S. (2019). Role of job stress on job satisfaction. International Journal of Management Studies, 4(4), 57 - 60. doi: 10.18843/ijms/v6i4/.

Smith, P.C., Kendall, L.M., \& Hulin C.L. (1969). In Omoluabi, P.F., (1997). Job Description Index Manual. Department of Psychology, University of Lagos.

Taoreed O., Jinadu G.O., \& Adeboye S.O., (2013). Validation of Depression Anxiety and Stress Scale in the Nigerian Military Population. Academia. https://www.academia.edu/35510637/VALIDATION_OF_DEPRESSION_ANXIETY_AND_STRESS_SC ALE IN THE NIGERIAN MILITARY POPULATION

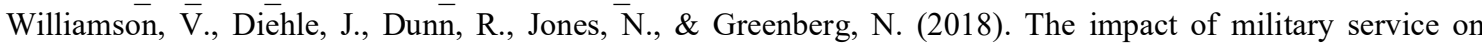
health and well-being. Occupational Medicine, $1-7$.

Yvonne, W., Rahman, R. H. A., \& Long, C. S. (2014). Employee job satisfaction and job performance: a case study in a Franchised Retail-Chain Organization. Research Journal of Applied Sciences, Engineering and Technology, 8(17), 1875-1883

Zhao, J., Thurman, Q., \& He, N. (1999), Sources of job satisfaction among police officers: a test of demographic and work environment models. Justice Quarterly, 16 (1), 153-173. 